\title{
Giant cell glioblastoma: review of the literature and illustrated case
}

\author{
J.M. Valle-Folgueral; L. Mascarenhas; J.A. Costa; F. Vieira*; J. Soares-Fernandes**; P. Beleza*** and C. Alegria
}

Neurosurgery Service. *Anatomic Pathology Service. **Neuroradiology Service. ***Neurology Service. São Marcos Hospital. Braga. Portugal.

\section{Summary}

Giant cell glioblastoma is an infrequent variety of glioblastoma ( $5 \%$ of the cases). It has deserved a separate category in the World Health Organization classification of grade IV tumors. The clinical, imaging, histological and immunohistochemical characteristics, and the genetic alterations are reviewed. Treatment and prognosis are discussed and updated. The case of a patient that survived 19 months and died of spinal leptomeningeal metastases is illustrated.

KEYWORDS: Giant cell glioblastoma. Leptomeningeal metastases. Surgery. Temozolomide. Radiotherapy.

Glioblastoma de células gigantes: revisión de la literatura e ilustración de un caso

\section{Resumen}

El glioblastoma de células gigantes es una variante rara dentro de los glioblastomas $(5 \%$ de los casos). En la clasificación de la Organización Mundial de la Salud esta entidad ha merecido una categoría aparte en los tumores de grado IV. Se revisan las características clínicas, radiológicas, histológicas, inmunohistoquímicas y las alteraciones genéticas que caracterizan este tumor. El tratamiento y el pronóstico son discutidos aportando información actualizada. Finalmente se presenta un caso clínico ilustrado, en el cual el paciente sobrevivió durante 19 meses, falleciendo como consecuencia de una diseminación espinal leptomeníngea.

PALABRAS CLAVE: Glioblastoma de células gigantes. Metástasis leptomeníngeas. Cirugía. Temozolomida. Radioterapia

Recibido: 3-01-08. Aceptado: 23-01-08

\section{Introduction}

Unlike the "common" glioblastoma, giant cell glioblastoma is not encountered in everyday practice and it probably comes as an unexpected diagnosis most of the times. Despite certain similarities between the two disease processes, there are differences that may be of relevance for the management of the occasional patient harboring this lesion. A case of giant cell glioblastoma managed at the authors' institution is reported and the key features of giant cell glioblastoma are reviewed.

\section{Clinical case}

A 54 year-old man presented with headache and motor dysphasia of short duration. MR disclosed a voluminous mass in the left temporal lobe (figure 1-A\&B). The patient was operated. A frontotemporal approach was employed. The lesion had a good cleavage plane, was moderately hemorrhagic and was totally resected in a piece meal fashion. The postoperative course was uneventful. Histological examination disclosed a highly cellular neoplasm with marked pleomorphism. Prominent giant cells and numerous atypical mitotic figures were found (figure 1-C). Reticulin was abundant in the stroma. Immunohistochemistry showed positivity for GFAP, S100 protein and p53. The picture was consistent with giant cell glioblastoma. Adjuvant radiotherapy (60Gy) and chemotherapy (temozolomide) were given. There was no evidence of relapse at the 14 month follow up MR (figure 1-D). The patient was symptom free and had no neurological deficits at that time. Three months after, the patient complained of backache, lower limb weakness and deteriorating general condition. MR disclosed spinal leptomeningeal metastases (figure 1E). Curiously there was no evidence of relapse at the original site. No further treatments were employed. The patient died 19 months after surgery.

\section{Comments}

"Common" glioblastoma is a diagnosis that implies 

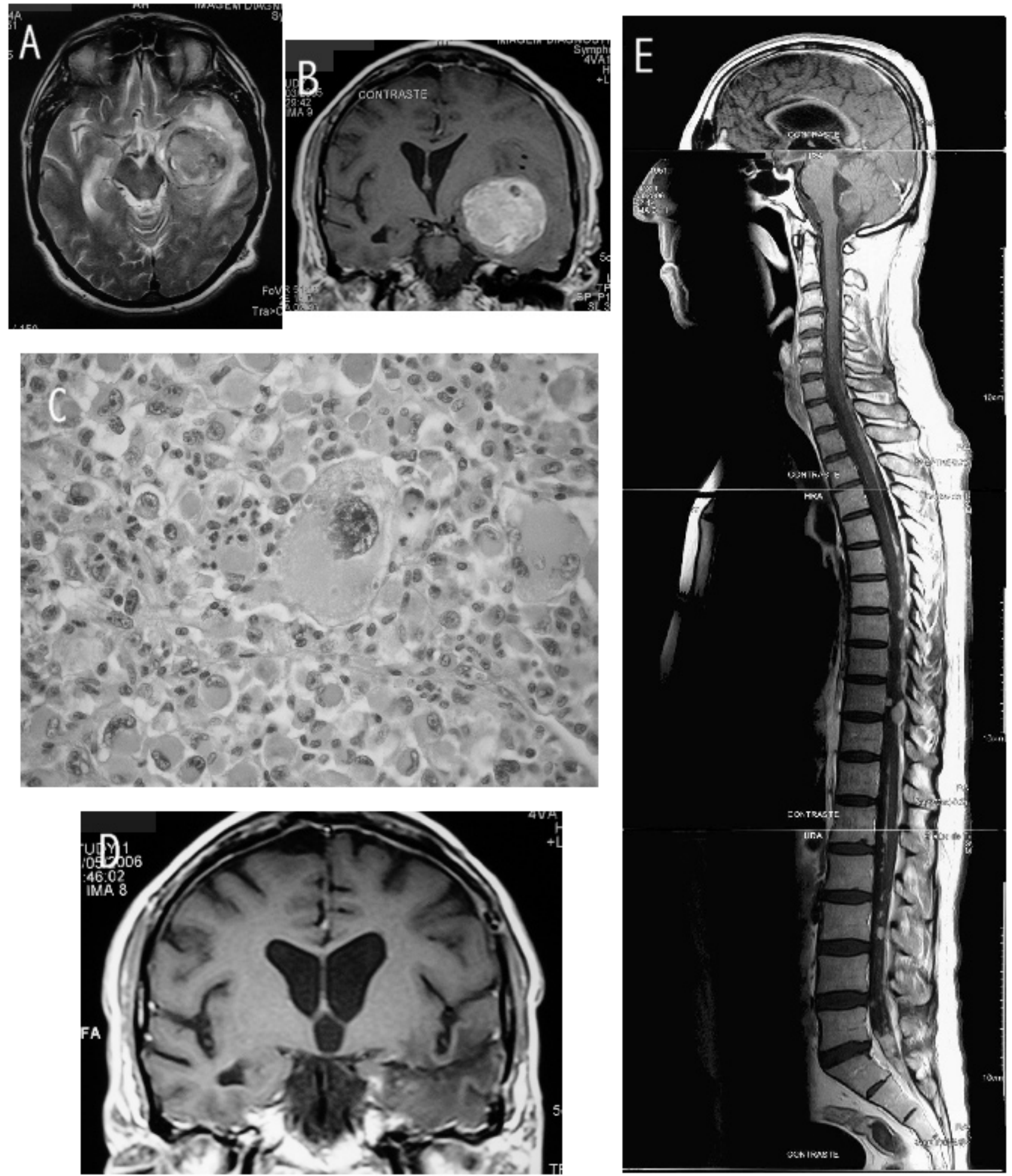

Figure 1. A: preoperative axial T2 weighted MR image; a quite homogeneous subcortical mass in the left temporal lobe with well defined borders and associated edema. B: preoperative coronal T1 weighted MR image; marked contrast enhancement is seen. $C$ : $H \& E$ stained slide high power view; a characteristic giant cell is present in the center of the field. D: postoperative coronal T1 weighted MR image 14 months after surgery; no mass and no contrast enhancement. E: postoperative sagital $T 1$ weighted MR image 17 months after surgery; spinal leptomeningeal metastases. 
most of the times a very short survival. Despite this being a case of giant cell glioblastoma, in the beginning it was not felt that its course would be very different. However, the patient responded very well to surgery and adjuvant treatments and the situation started to be regarded with some enthusiasm and optimism. Nevertheless, relapse occurred and it came in a somewhat unexpected fashion.

\section{Review of the literature}

Giant cell glioblastoma has merited a separate category in the World Health Organization (WHO) classification of tumors as a grade IV tumor of astrocytic origin ${ }^{36}$. Microscopically, giant cells with nuclei of variable number, size and shape are the characteristic feature. These cells may reach up to $500 \mu \mathrm{m}$. Cells of small dimension are seen as well. The lesion is highly cellular. In certain cases abundant stromal reticulin fibers can be found. Prominent nucleoli, typical and atypical mitotic figures, and irregularly shaped chromatin fragments are encountered. Necrosis is present, namely in pseudo-palisading or large ischemic forms. The accumulation of tumor cells around blood vessels may originate pseudo-rosette formation. An in vitro study showed that some giant multinucleated cells might have originated from the conversion of a number of small tumor cells, also of astrocytic origin ${ }^{20}$. Giant tumor cells may show lipid accumulation $^{27,41}$, and abundant microcalcifications may be present as well ${ }^{27}$. Infiltration of the tumor by cells pertaining to the immune system can be prominent, namely mononuclear leukocytes ${ }^{44}$ and eosinophilic granulocytes ${ }^{35}$. Cellular whorls can also be a feature of the tumor ${ }^{23}$. Cytology may give a clear, even diagnostic, impression of the tumor at the time of surgery ${ }^{16}$. A mixed ganglion cell tumor - giant cell glioblastoma morphology has been described ${ }^{10}$, as well as the presence of an oligodendroglial component ${ }^{26}$.

The correct origin and classification of the tumor has been determined by immunohistochemistry profiles. Glial fibrillary acidic protein (GFAP) positivity supports the glial origin of the lesion, and thereby turns inadequate the previously used designation "monstrocellular sarcoma" ${ }^{33}$. Immunohistochemistry studies show staining of tumor cells for GFAP ${ }^{21,22}$, vimentin ${ }^{21,22}$ S-100 protein ${ }^{21}$, and alpha1 anti-chymotrypsin ${ }^{22}$. GFAP staining is equally intense over perikaryons and processes ${ }^{43,48}$. There may be a focal dissociation of immunoreactivity for GFAP and S-100 protein $^{24}$.

An important differential histological diagnosis of giant cell glioblastoma is pleomorphic xanthoastrocytoma. They have in common the presence of giant tumor cells, infiltration of lymphocytes, deposition of reticulin and gross circumscription $^{31}$. It has been hypothesized that in young girls giant cell glioblastoma may derive from pleomorphic xanthoastrocytoma ${ }^{21}$. The question of a possible progres- sion of anaplastic pleomorphic xanthoastrocytoma (WHO grade III) from pleomorphic xanthoastrocytoma (WHO grade II) towards giant-cell glioblastoma (WHO grade IV) has been raised ${ }^{49}$. Clinical and histological criteria that aid in the differentiation between giant cell glioblastoma and pleomorphic xanthoastrocytoma have been summarized; quicker evolution of seizures, numerous great sized giant cells, numerous mitoses, atypical mitoses and necrosis with pseudo-palisading will favor giant cell glioblastoma ${ }^{11}$. Different immunohistochemical profiles for neuronal antigens (class III beta-tubulin, neuronal nuclear antigen, neurofilament protein, synaptophysin, GFAP) and p53 allow for the differentiation between giant cell glioblastoma and pleomorphic xanthoastrocytoma. GFAP and class III beta-tubulin are positive in both tumors. Positivity for p53 is seen in giant cell glioblastoma but not in pleomorphic xanthoastrocytoma. Negativity for neuronal nuclear antigen, neurofilament protein and synaptophysin is seen in giant cell glioblastoma but not in pleomorphic xanthoastrocytoma ${ }^{31}$. A more difficult differential is with anaplastic pleomorphic xanthoastrocytoma; in the latter the labeling index will not rise beyond $14 \%$; mitoses, although possibly more than $5 / 10$ high power fields will not reach a number as high as that of a giant cell glioblastoma (15-20/10 high power fields); slower clinical course and lack of great sized giant cell are also expected ${ }^{11}$.

Giant cell glioblastoma represents $0.8 \%$ of brain tumors and $5 \%$ of glioblastomas in general ${ }^{37}$. Giant cell glioblastoma predominates in the cerebral hemispheres, mainly subcortically in the temporal and parietal lobes ${ }^{36}$. Other possible primary locations include the cerebellum $^{14,22,41}$ the lateral ventricles ${ }^{3}$, the optic chiasm $^{7}$ and the spinal $\operatorname{cord}^{17}$. The lesion can be multifocal ${ }^{38}$. Spinal leptomeningeal metastases ${ }^{9}$, and extraneural metastases ${ }^{46}$ have been reported. The duration of symptoms is usually short, and the clinical presentation is similar to that of "common" glioblastoma ${ }^{36}$. On occasion it may be somewhat atypical such as intracerebral hemorrhage in the context of traffic accident $^{8}$, or cranial-spinal subarachnoid hemorrhage 9 The mean age at presentation has been calculated to be 42 years and a male predominance described ( $\mathrm{M} / \mathrm{F}$ ratio 1.6$)$; $35 \%$ occur in people under 40 years $^{36}$. Possible associated disorders of genetic origin include neurofibromatosis type $1^{27}$ and tuberous sclerosis ${ }^{2}$. In the sequence of the study of central nervous system tumors induced in primates, an association of human giant cell glioblastoma with JC virus or progressive multifocal leukoencephalopathy has been hypothesized ${ }^{32}$.

Recently, the total number of published cases in the "pediatric age group" has been estimated to be 53 since 1952 , and in a large series of pediatric brain tumors, giant cell glioblastoma constituted $1 / 364(0.2 \%)^{11}$. Cases in patients aged less than 10 years old have been estimated 
to constitute $6 \%$, and those in patients between 10 and less than 20 years $9 \%$ of the total ${ }^{36}$. One case has been reported in a child only 1 -year-old ${ }^{2}$.

From the imaging perspective giant cell glioblastoma has been described as a well demarcated lesion, but no distinguishing features were found when compared to the "common" glioblastoma'. However, the lesion can evolve from well circumscribed and homogeneous, to infiltrative and heterogeneous in a four month period ${ }^{8}$. Magnetic resonance (MR) may disclose a contrast enhancing heterogeneous mass, with solid and cystic areas, hypointense on T1 weighted sequences, hyperintense on T2 weighted sequences, surrounded by edema ${ }^{14}$. The cyst with mural nodule appearance has been described as well ${ }^{9}$. The value of MR spectroscopy, diffusion weighted imaging and perfusion imaging in addition to routine MR imaging have been emphasized; these techniques may offer clues that allow for a better differential diagnosis between glioblastomas, the giant cell variety included, and other pathologies ${ }^{14}$.

The treatment strategy has generally included surgery which by itself may offer 32 weeks of mean survival time ${ }^{37}$; one anecdotic patient treated with surgery alone survived for 17 years and 9 months and died of an unrelated cause ${ }^{44}$. Intraoperatively the tumor has been described as friable, moderately vascularized, amenable to suction, partially cystic and with a good cleavage plane ${ }^{3}$; another report describes it as solid, firm and well demarcated ${ }^{44}$; adhesion to the dura can occur ${ }^{51}$. The benefit of adjuvant treatment with radiotherapy has been established, adding 25 weeks to the total mean survival time ${ }^{37}$. Use of chemotherapy has been described as well, although protocols are quite variable 26,47,51 $^{\text {. }}$.

Anecdotic cases of extremely long survival ranging from 11 to 17 years without evidence of recurrence have been reported $26,27,44,51$. In a case of recurrence of giant cell glioblastoma nine years after the initial diagnosis, progression to gliosarcoma occurred ${ }^{12}$. Nevertheless, the patient, an 8-year- old child, had more than 10 years of total survival. Possible causes of the sarcomatous transformation may include radiotherapy and a phenotypic change of the tumor cells. Nevertheless, cases of extreme success are tempered by other reports; recurrence just one month after apparent total removal in a child has been reported ${ }^{11}$; in a series of seven patients, the lesion was described as having a highly malignant behavior and all were dead within 14 months despite aggressive treatment ${ }^{18}$; three out of ten patients died within 3 days of surgery ${ }^{30}$.

A positive relationship has been shown between the length of survival of patients with glioblastomas and the presence of the giant cell variety ${ }^{6}$. Adding two recent clinical series of patients harboring glioblastomas that survived for more than five years constituting as a whole 12 cases, one third $(n=4)$ had giant cell glioblastoma ${ }^{13,47}$. Infiltration of the tumor by leukocytes has been regarded as a good prognostic factor in view of the enhanced immune response of the organism that it may represent ${ }^{37,44}$; giant cells in this respect may function as magnifiers of the antigenic stimulus $^{37}$. The presence of a fibrous stroma in giant cell glioblastoma may contribute to a precise delimitation of the tumor thereby facilitating radical surgical excision, a factor that may have some association with prolonged survival ${ }^{44}$. Alpha I antitrypsin detected with relatively high frequency in the giant cells may explain the bizarre size and pericellular reticulin fiber formation ${ }^{21}$.

In giant cell glioblastoma gene p53 (syn. TP53) has a mutation in $75-89 \%$ of the cases ${ }^{34,39}$. Mutations have been studied in detail at the molecular level and reported: codon $285, \mathrm{G}$ to $\mathrm{A}$ transition results in a glutamic acid to lysine substitution ${ }^{19}$; G $>$ A transition at nucleotide 524, substitution of arginine by histidine at position 175 of the p53 protein ${ }^{44}$. The p53 gene is located on chromosome 17 and is regarded a guardian of the genome; p53 protein is involved in cell cycle arrest and apoptosis when DNA is damaged ${ }^{28}$. Mutant p53 proteins are stable and can be detected by immunohistochemistry. These techniques disclose positivity for p53 protein in giant cell glioblastoma. Although the gene may be mutated and staining for the protein absent, and the protein may be found without a mutated gene, nuclear immunoreactivity for p53 protein is associated with an increased frequency of p53 gene mutation ${ }^{31}$. Approximately $30 \%$ frequency of PTEN (phosphatase and tensin homologue) gene mutations is recorded in giant cell glioblastoma ${ }^{40}$. The PTEN gene is located on chromosome 10 and it is related to cell cycle arrest, apoptosis and inhibition of cell motility; mutation allows cell division ${ }^{28}$. Strong survivin immunoreactivity has been shown for giant cell glioblastoma. The staining is only cytoplasmic. Survivin functions as an inhibitor of apoptosis protein. A trend exists towards survivin expression and higher grade of astrocytic tumors. However, this does not necessarily imply rapid division and poor prognosis since the marker is overexpressed in meningiomas and benign peripheral nerve sheath tumors ${ }^{45}$. A chromosomal abnormality consisting of loss of $17 \mathrm{p}, 1 \mathrm{p}$ and $19 \mathrm{q}$ has been described for giant cell glioblastoma; the combination of $1 p$ and $19 q$ deletions has been associated with a better prognosis ${ }^{4}$. Loss of $10 \mathrm{p} 15$ in a subpopulation of tumor cells has been described ${ }^{44}$. Epidermal growth factor receptor (EGFR) gene amplification, a genetic alteration with growth promoting potential, is not significant, and does not seem to play a role in the evolution of the tumor ${ }^{34,39}$. Similar considerations apply to genes CDK4-MDM2 $2^{40,44}, \mathrm{n}-\mathrm{myc}^{5}, \mathrm{c}-\mathrm{myc}^{5}$ and gli ${ }^{5}$. There is a relative absence of CDKN2A deletion, a genetic alteration with growth promoting potential ${ }^{34}$. Defects of mitotic spindle checkpoint gene hBUB1 do not seem to be implicated in giant cell glioblastoma as a cause of chromosomal 
instability leading to aneuploidy. Mitotic checkpoint has to do with a delay in anaphase if spindle damage is present in order to increase the probability of delivering an euploid genome to the daughter cells ${ }^{42}$. Immunoreactivity for neurotrophin Trk A and Trk B receptors is low in giant cell glioblastoma. Neurotrophin Trk A and Trk B receptors have been implied in tumor pathogenesis in an early stage. They respond to signals that elicit glial proliferation and are regarded as a factor of progression towards malignancy in low grade lesions where high levels of immunoreactivity are present ${ }^{50}$. Overall, in what genomic aberrations are concerned, these have been classified as scarce when compared to the number usually present in the "common" glioblastoma, and some changes associated with a dismal prognosis (e.g. EGFR gene amplification, CDKN2A homozygous deletion) are not found ${ }^{44}$.

A somewhat elevated proliferation index of $25 \%$ (Ki-67 nuclear antigen labeling index identified through MIB-1 antibody) has been implicated as a factor responsible for the very early relapse of the tumor (expected figure for the "common" glioblastoma would be $15-20 \%$, for cases of long survival $<18 \%$, for cases with poor prognosis $>36 \%$ ); microscopic tumor rests not visible in post-operative MR images were also considered of significance ${ }^{11}$. Giant cells synthesize DNA and the progression might be related to mutated tumor suppressor gene $\mathrm{p} 53^{22}$. Markers of proliferative potential such as proliferating cell nuclear antigen (PCNA) and Ki-67 can be strongly positive in the nuclei of multinucleated giant cells, especially in adult cases ${ }^{21}$. However, this should be interpreted in the context of the global behavior of the cell. Prognosis has been said to be determined by the biological behavior of mononucleated giant cells and small cells ${ }^{18}$. Multinucleated giant cells do not result from either cell fusion or cell degeneration. They seem to be cells that remain in mitosis between metaphase and telophase; the nuclei undergo division but the cytoplasm doesn't. Multinucleated giant cells do not seem to have proliferative activity. Mononucleated cells on the contrary have this capacity and, if present in a significant proportion, may imply a worse prognosis ${ }^{29}$. Aurora-B is a kinase that functions in early and late mitotic events, chromosome segregation / condensation and cytokinesis. Aurora-B dysfunction has been shown in multinucleated giant tumor cells. This will cause aberrations in cytoplasmic cleavage without affecting nuclear division ${ }^{15}$.

Clinically and genetically giant cell glioblastoma has been placed in an intermediate position between the de novo "common" glioblastoma (primary type) and the "common" glioblastoma deriving from a precursor lesion (secondary type $)^{25}$. Giant cell glioblastoma shares with secondary "common" glioblastoma p53 mutations in more than $70 \%$ of the cases and younger patient age at presentation; features shared with primary "common" glioblastoma are 30\% frequency of PTEN mutations, short clinical history and absence of less malignant precursor lesion ${ }^{40}$. Overall, analyses of survival in large series seem to agree that the prognosis is somewhat better than that of "common" glioblastoma, e.g., 38 cases - 27.4 months average postoperative survival ${ }^{35} 24$ cases -57 weeks mean survival time $^{37}$.

\section{Conclusion}

Giant cell glioblastoma has a more benign entourage than "common" glioblastoma. Nevertheless, the individual patient variables and the biological features of the tumor, despite the giant cell morphology, should be well taken into account since an ominous course is also a possibility.

\section{References}

1. Akslen, L.A., Mork, S.J., Larsen, J.L., et al.: Giant cell glioblastoma: a work-up of 2 cases with long survival. Acta Neurol. Scand. 1989; 79: 194-199.

2. Al-Saleem, T., Wessner, L.L., Scheithauer, B.W., et al.: Malignant tumors of the kidney, brain, and soft tissues in children and young adults with the tuberous sclerosis complex. Cancer 1998; 83: 2208-2216.

3. Alvarez-Betancourt, L., López-Ortega, S., CalderaDuarte, A.: Giant cell glioblastoma. Case report. [in Spanish] Gac. Med. Mex. 2004; 140: 341-342.

4. Arslantas, A., Artan, S., Oner, U., et al.: The importance of genomic copy number changes in the prognosis of glioblastoma multiforme. Neurosurg. Rev. 2004; 27: 58-64.

5. Bigner, S.H., Burger, P.C., Wong, A.J., et al.: Gene amplification in malignant human gliomas: clinical and histopathologic aspects. J. Neuropathol. Exp. Neurol. 1988; 47 : 191-205.

6. Burger, P.C., Vollmer, R.T.: Histologic factors of prognostic significance in the glioblastoma multiforme. Cancer 1980; 46: 1179-1186.

7. Burnstine, M.A., Levin, L.A., Louis, D.N., et al.: Nucleolar organizer regions in optic gliomas. Brain 1993; 116: 1465-1476.

8. Can, S.M., Aydin, Y., Turkmenoglu, O., et al.: Giant cell glioblastoma manifesting as traumatic intracerebral hemorrhage - case report. Neurol. Med. Chir. 2002; 42: 568-571.

9. Chang, C.C., Kuwana, N., Ito, S., et al.: Spinal leptomeningeal metastases of giant cell glioblastoma associated with subarachnoid hemorrhage: case report. J. Clin. Neurosci. 2001; 8: 56-59.

10. Dash, R.C., Provenzale, J.M., McComb, R.D., et al.: Malignant supratentorial ganglioglioma (ganglion cell - giant cell glioblastoma): a case report and review of the literature. Arch. Pathol. Lab. Med. 1999; 123:3 42-345.

11. De Prada, I., Cordobes, F., Azorín, D., et al.: Pediatric 
giant cell glioblastoma: a case report and review of the literature. Childs. Nerv. Syst. 2006; 22: 285-289.

12. Deb, P., Sharma, M.C., Chander, B., et al.: Giant cell glioblastoma: report of a case with prolonged survival and transformation to gliosarcoma. Childs. Nerv. Syst. 2006; 22: 314-319.

13. Deb, P., Sharma, M.C., Mahapatra, A.K., et al.: Glioblastoma multiforme with long term survival. Neurol. India 2005; 53: 329-332.

14. Demir, M.K., Hakan, T., Akinci, O., et al.: Primary cerebellar glioblastoma multiforme. Diagn. Interv. Radiol. 2005; 11: 83-86.

15. Fujita, M., Mizuno, M., Nagasaka, T., et al.: Aurora-B dysfunction of multinucleated giant cells in glioma detected by site-specific phosphorylated antibodies. J. Neurosurg. 2004; 101: 1012-1017.

16. Gandolfi, A., Tedeschi, F., Brizzi, R.: Cytology of giant-cell glioblastoma. Acta Cytol. 1983; 27: 193-197.

17. Grisold, W., Pernetzky, G., Jellinger, K.: Giant-cell glioblastoma of the thoracic cord. Acta Neurochir. 1981; 58: 121-126.

18. Huang, M.C., Kubo, O., Tajika, Y., et al.: A clinicoimmunohistochemical study of giant cell glioblastoma. Noshuyo Byori 1996; 13: 11-16.

19. Hunter, S.B., Bandea, C., Swan, D., et al.: Mutations in the p53 gene in human astrocytomas: detection by singlestrand conformation polymorphism analysis and direct DNA sequencing. Mod. Pathol. 1993; 6: 442-445.

20. Ibayashi, N., Herman, M.M., Boyd, J.C., et al.: Kinetics and glial fibrillary acidic protein production in a transplantable human giant cell glioblastoma (D-212 MG) of near haploid karyotype maintained in an organ culture system. An immunohistochemistry study. Neuropathol. Appl. Neurobiol. 1990; 16: 27-37.

21. Katoh, M., Aida, T., Sugimoto, S., et al.: Immunohistochemical analysis of giant cell glioblastoma. Pathol. Int. 1995; 45: 275-282.

22. Kawano, H., Kubota, T., Sato, K., et al.: Immunohistochemical study of giant cell in glioblastoma. Clin. Neuropathol. 1995; 14: 118-123.

23. Kepes, J.J.: Cellular whorls in brain tumors other than meningiomas. Cancer 1976; 37: 2232-2237.

24. Kimura, T., Budka, H., Soler-Federsppiel, S.: An immunocytochemical comparison of the glia-associated proteins glial fibrillary acidic protein and S-100 protein in human brain tumors. Clin. Neuropathol. 1986; 5: 21-27.

25. Kleihues, P., Ohgaki, H.: Phenotype vs genotype in the evolution of astrocytic brain tumors. Toxicol. Pathol. 2000; 28: 164-170.

26. Klein, R., Molenkamp, G., Sorensen, N., et al.: Favorable outcome of giant cell glioblastoma in a child. Report of an 11-year survival period. Childs. Nerv. Syst. 1998; 14: 288291.
27. Kroh, H., Matyja, E., Marchel, A., et al.: Heavily lipidized, calcified giant cell glioblastoma in an 8-year-old patient, associated with neurofibromatosis type 1: report of a case with long-term survival. Clin. Neuropathol. 2004; 23: 286-291.

28. Kumar, V., Abbas, A.K., Fausto, N.: Robbins and Cotran pathologic basis of disease $7^{\text {th }}$ edition. Philadelphia; Elsevier Saunders, 2005; pp. 269-342.

29. Maeda, K., Mizuno, M., Wakabayashi, T., et al.: Morphological assessment of the development of multinucleated giant cells in glioma by using mitosis-specific phosphorylated antibodies. J. Neurosurg. 2003; 854-859.

30. Margetts, J.C., Kalyan-Raman, U.P.: Giant-celled glioblastoma of brain. A clinico-pathological and radiological study of ten cases (including immunohistochemistry and ultrastructure). Cancer 1989; 63: 524-531.

31. Martínez-Díaz, H., Kleinschmidt-DeMasters, B.K., Powell, S.Z., et al.: Giant cell glioblastoma and pleomorphic xanthoastrocytoma show different immunohistochemical profiles for neuronal antigens and p53 but share reactivity for class III beta-tubulin. Arch. Pathol. Lab. Med. 2003; 127: 1187-1191.

32. McKeever, P.E., Chronwall, B.M., Houff, S.A., et al.: Glial and divergent cells in primate central nervous system tumors induced by JC virus isolated from human progressive multifocal leukoencephalopathy. Prog. Clin. Biol. Res. 1983; 105: 239-251.

33. McKeever, P.E.: Insights about brain tumors gained through immunohistochemistry and in situ hybridization of nuclear and phenotypic markers. J. Histochem. Cytochem. 1998; 46: 585-594.

34. Meyer-Puttlitz, B., Hayashi, Y., Waha, A., et al.: Molecular genetic analysis of giant cell glioblastomas. Am. J. Pathol. 1997; 151: 853-857.

35. Muller, W., Slowik, F., Firsching, R., et. Al.: Contribution to the problem of giant cell astrocytomas. Neurosurg. Rev. 1987; 10: 213-219.

36. Ohgaki, H., Peraud, A., Nakazato, Y., et al.: Giant cell glioblastoma. In Kleihues, P., Cavenee, W.K. (eds). World Health Organization classification of tumours. Pathology and genetics of tumours of the nervous system. Lyon; IARC Press, pp. $40-41$.

37. Palma, L., Celli, P., Maleci, A., et al.: Malignant monstrocellular brain tumors. A study of 42 surgically treated cases. Acta Neurochir. 1989; 97: 17-25.

38. Parekh, H.C., Sharma, R.R., Prabhu, S.S., et al.: Multifocal giant cell glioblastoma: case report. Surg. Neurol. 1993; 40: 151-154.

39. Peraud, A., Watanabe, K., Plate, K.H., et al.: p53 mutations versus EGF receptor expression in giant cell glioblastomas. J. Neuropathol. Exp. Neurol. 1997; 56: 12361241.

40. Peraud, A., Watanabe, K., Schwechheimer, K., et al.: 
Genetic profile of the giant cell glioblastoma. Lab. Invest. 1999; 79: 123-129.

41. Queiroz, L.S., Faria, A.V., Zanardi, V.A., et al.: Lipidized giant-cell glioblastoma of cerebellum. Clin. Neuropathol. 2005; 24: 262-266.

42. Reis, R.M., Nakamura, M., Masuoka, J., et al.: Mutation analysis of hBUB1, HBUBR1 and hBUB3 genes in glioblastomas. Acta Neuropathol. 2001; 101: 297-304.

43. Reyaz, N., Tayyab, M., Khan, S.A., et al.: Correlation of glial fibrillary acidic protein with grading of the neuroglial tumours. J. Coll. Physicians Sur. Pak. 2005; 15: 472-475.

44. Sabel, M., Reifenberger, J., Weber, R.G., et al.: Longterm survival of a patient with giant cell glioblastoma. Case report. J. Neurosurg. 2001; 94: 605-611.

45. Sasaki, T., Lopes, M.B., Hankins, G.R., et al.: Expression of survivin, an inhibitor of apoptosis protein, in tumors of the nervous system. Acta Neuropathol. 2002; 104: 105-109.

46. Shinmura, F., Chen, M., Itoh, T., et al.: An autopsy case of extraneural metastases of giant cell glioblastoma with intracerebral hemorrhage. [in Japanese] No Shinkei Geka 1985; 13: 1245-1250.

47. Shinojima, N., Kochi, M., Hamada, J., et al.: The influence of sex and the presence of giant cells on postoperative long-term survival in adult patients with supratentorial glioblastoma multiforme. J. Neurosurg. 2004; 101: 219-226.

48. Tascos, N.A., Parr, J., Gonatas, N.K.: Immunocytochemical study of the glial fibrillary acidic protein in human neoplasms of the central nervous system. Hum. Pathol. 1982; 13: 454-458.

49. Tekkok, I.H., Sav, A.: Anaplastic pleomorphic xanthoastrocytomas. Review of the literature with reference to malignancy potential. Pediatr. Neurosurg. 2004; 40:1 71181.

50. Wadhwa, S., Nag, T.C., Jindal, A.: Expression of the neurotrophin receptors Trk A and Trk B in adult human astrocytoma and glioblastoma. J. Biosci. 2003; 28: 181-188.

51. Yoshida, T., Kawano, N., Oka, H., et al.: Clinical cure of glioblastoma. Two case reports. Neurol. Med. Chir. 2000; 40: 224-229.

Valle-Folgueral, J.M.; Mascarenhas, L.; Costa, J.A.; Vieira, F.; Soares-Fernandes, J.; Beleza, P,; Alegria, C.: Giant cell glioblastoma: review of the literature and illustrated case. Neurocirugía 2008; 19: 343-349.

Correspondence: Dr. Lino Mascarenhas. Serviço de Neurocirurgia. Hospital de São Marcos. Apartado 2242. 4701-965 Braga. Portugal. 